\title{
CHARACTERISATION OF LACTIC ACID BACTERIA ISOLATED FROM KEFIR MILK MADE FROM DAIRY AND NON-DAIRY SOURCES AND THEIR SENSORY ACCEPTANCE
}

\author{
CHAN KHER ZHI ${ }^{1}$, MOHD NIZAM LANI*1,2, YUSNITA HAMZAH ${ }^{1}$, FAUZIAH TUFAIL \\ AHMAD $^{1}$ AND NIK HAFIZAH NIK UBAIDILLAH ${ }^{3}$
}

${ }^{1}$ Faculty of Fisheries and Food Science, Universiti Malaysia Terengganu, 21030 Kuala Nerus, Terengganu, Malaysia ${ }^{2}$ Institute of Marine Biotechnology, Universiti Malaysia Terengganu, 21030 Kuala Nerus, Terengganu, Malaysia

${ }^{3}$ Food Science and Technology Research Centre, MARDI Kuala Terengganu, 20700 Kuala Terengganu, Terengganu, Malaysia

*Corresponding author: nizamlani@umt.edu.my

http://doi.org/10.46754/umtjur.2021.04.004

\begin{abstract}
Kefir is a fermented milk obtained by fermenting milk with kefir grains. The chemical composition of dairy and non-dairy sources may affect the growth and characterisation of lactic acid bacteria (LAB). In this study, different sources of milk (cow milk) and non-dairy milk (soymilk and coconut milk) were used as the fermentation media for kefir products. The objectives of the study were to isolate and characterise LAB from kefir drink produced from dairy and non-dairy milk. LAB was isolated using different cultural methods, such as MRS Agar, MRS with $0.8 \% \mathrm{CaCO}_{3}$, and M17 Agar. The characteristics of the LAB isolates were determined using morphological, biochemical tests and the API 50 CHL kit. The physicochemical composition of the samples was determined using titratable acidity and $\mathrm{pH}$ level. Sensory evaluation of the kefir drink samples was also carried out. Results confirmed that the isolates were identified as Lactobacillus buchneri, Lactobacillus brevis 1, Leuconostoc mesenteroides, Lactobacillus acidophilus 3 and Lactobacillus plantarum 1. The L. buchneri, L. brevis, Leu. mesenteroides and L. acidophilus are heterofermentative bacteria, whereas L. plantarum is a homofermentative bacterium. Four LAB isolates have the potential to be used as probiotic strains due to their high resistant to low $\mathrm{pH}$ and bile salt. The sensory scores of these products range between 5.00 and 8.00 in the 9-point hedonic scale. Most of the sensory panelists preferred cow milk kefir $(p<0.05)$ compared with coconut milk kefir and soy milk kefir during the sensory evaluation of all attributes. Meanwhile, the preference between coconut milk kefir and soy milk kefir was similar $(p>0.05)$ in all attributes. Therefore, this study will be useful for probiotic manufacturers in the production of alternative probiotic drinks using dairy and non-dairy milk.
\end{abstract}

Keywords: Kefir milk, lactic acid bacteria, lactose intolerance, fermented food, probiotic foods, nondairy milk product

\section{Introduction}

Kefir is a cultured and fermented milk product that is created through the symbiotic fermentation of milk by lactic acid bacteria (LAB) and yeast contained in an exopolysaccharides and protein complex called a kefir grain (Bourrie et al., 2016). Historically, kefir is a traditional drink that is well-known in the Middle East and it is traditionally consumed in Turkey. The word "kefir" is said to have originated from the Turkish word "keyif", which means "good feeling" (Otles \& Cagindi, 2003). Kefir is a fermented milk-based beverage that is cultured with microflora encased in kefir grains. It is a yellowish white beverage with a sour flavour and is slightly carbonated as it contains a small quantity of alcohol. It was originated by shepherds of the North Caucasus region and they described kefir as a pleasurable, frothy milk drink (Gaware et al., 2011). Kefir can be made from dairy and non-dairy milk sources and is prepared by inoculating the milk sources with kefir grains, which contains LAB and yeast that live symbiotically (Gaware et al., 2011). 
LAB are rod or cocci shaped bacteria, which are characterised as Gram-positive, non-motile and non-spore forming bacteria. LAB belong to the Firmicutes phylum, Bacilli class, and Lactobacillus order, which includes six families. To date, 43 genera have been described (RuizRodríguez et al., 2016). LAB is also characterised by their production of lactic acid as their main product through lactic fermentation. Generally, LAB is industrially used as a starter culture and as a probiotic, and they play a very important role in the production of fermented foods (RuizRodríguez et al., 2016). Some LAB strains are characterised as probiotic as they can survive under stressful environmental conditions, such as being resistant to acidic gastric juice, being able to adhere to the gastrointestinal (GI) tract and exhibiting antagonistic action against pathogens (Rattanachaikunsopon \& Phumkhachorn, 2010). LAB have been widely used to improve the preservation, nutritional value, and sensory characteristics in fermented and probiotic foods (Lee et al., 2019). Previous studies by Lani et al. (2015) has shown that the use of crude bacteriocin of LAB was effective in controlling microbial growth in 'Satar', a readyto-eat food product in Terengganu.

The fermentation process of milk also makes it easier to digest, especially for those who are lactose intolerant. It also increases the shelf-life of the milk product. During fermentation, amino acids and peptides are present due to microbial digestion, similar to the base ingredient, which reduces its difficulty in terms of consumption. Fermented milk products have lower lactose levels compared with milk, which have higher lactose levels. The lactose that presents in milk is hydrolysed by microbial beta-galactosidase during fermentation to produce galactose and glucose, making fermented milk products useful for those who are lactose intolerant (McKevith \& Shortt, 2003).

Kefir and yogurt are the oldest and most popular types of fermented milk. Non-dairy probiotic foods were produced and manufactured due to the high demand of consumers for alternatives to dairy probiotic foods (Grabato et al., 2010). The problem with intolerance and allergy, desire for vegetarian alternatives further increased the demand for non-dairy probiotic foods. Soybean, which is the important legume that is common in Asian diets, has a high protein content. Soy milk is commonly used as a substitute for dairy milk by those who are unable to digest a significant amount of lactose, which is the major milk sugar in dairy milk. The consumption and availability of cow milk has decreased, whereas the consumption and the availability of non-dairy milk is increasing due to the fact that cow milk is much more expensive than non-dairy milk (Hass et al., 2019). Today, soy milk, a non-dairy milk, and its derivatives have attracted the attention of consumers and researchers all around the world due to its high protein content. Kefir can be made from dairy and non-dairy milk sources and is prepared by inoculating the milk sources with kefir grains, which contains LAB and yeast that live symbiotically. According to Magalhães et al. (2011), LAB was the predominant group $(60.5 \%)$ in Brazilian kefir beverage, followed by yeasts $(30.6 \%)$ and acetic acid bacteria (8.9\%).

Numerous studies have been carried out to study on fermented foods. However, there are limited studies on kefir milk, especially on the prevalence of LAB strains that were isolated from kefir milk produced in Malaysia, which are made from different milk substrates. Modern consumers are increasingly conscious and interested in their personal health and expect the food that they consume to be healthy and capable of preventing illness. According to Mattila-Sandholm et al. (2002), the probiotic yogurt market is well established, but the key growth sector recently has been probiotic drinks. Hence, more natural alternatives and efforts are required to develop probiotic drinks outside the dairy sector. India is the largest producer of milk and it has the greatest advantage in the probiotic field, along with its booming economy, as Indian probiotic drinks are evolving at a steady pace with conditions set for tremendous growth in the near future (Raja \& Arunachalam, 2011). Therefore, the objectives of this study are to identify the LAB from different kefir milks and 
determine their physicochemical properties, as well as perform a sensory evaluation of the kefir products made from cow milk, coconut milk and soy milk.

\section{Materials and methods}

\section{Sources of Milk Samples}

Cow milk, coconut milk and soy milk were purchased from the same suppliers throughout this research. The suppliers of the milk samples were Dairy Industry Service Centre, Bukit Payong, Kuala Terengganu (cow milk), Santan Segar Gong Badak, Kuala Terengganu (fresh coconut milk), and China Town, Kuala Terengganu (homemade soy milk). Kefir grains were purchased from My Kefir World (@ mykefirworld), Cheras, Kuala Lumpur.

\section{Preparation of Kefir Milk Production}

Cow milk, coconut milk and soy milk were fermented traditionally and aseptically with kefir grains for the production of kefir milk as described by Ot1es and Cagindi (2003). The raw cow milk, coconut milk and soy milk were boiled in three different glass jars and cooled to $20-25^{\circ} \mathrm{C}$ and inoculated with $5 \%$ kefir grain purchased from supplier My Kefir World. After a period of fermentation at $18-24 \mathrm{~h}$ at $20-25^{\circ} \mathrm{C}$, the grains were separated from the milk by filtering with a sieve and dried at room temperature $\left(25^{\circ} \mathrm{C}\right.$ $\pm 2)$. Kefir milks in the sterile jar $(500 \mathrm{ml})$ were then kept in a chiller at $4^{\circ} \mathrm{C}$ for storage purposes.

\section{Isolation of LAB from Different Kefir Milks}

The isolation of LAB from different milk substrates of kefir milks were performed by sequences of serial dilution and incubation at $30{ }^{\circ} \mathrm{C}$ for 24 to $48 \mathrm{~h}$ in anaerobic conditions. Appropriate serial dilutions with $0.85 \%$ saline water were carried out to ensure colonies grown on the plates were not overgrown. The final dilution was then spread plated on three selectively media, which were MRS, M17 and MRS with $0.8 \% \mathrm{CaCO}_{3}$ Agar. The presumptive of $\mathrm{LAB}$ isolates were selectively tested for characterisation tests. LAB isolates with Grampositive characteristic and catalase negative were conserved in slanted agar at $4^{\circ} \mathrm{C}$.

\section{Morphological Characterisation of LAB}

The morphology of the pure cultures of LAB isolates were carried out using Gram staining, endospore staining and scanning electron microscopy (SEM) methods. A single colony of LAB isolates from agar plates were selected to perform all these methods. In the Gram staining method, the smear of well-isolated LAB colony with one drop of distilled water was fixed on a glass slide with heat. The heat-fixed smear was stained with crystal violet staining reagent for 1 minute and rinsed with running tap water. The smear was flooded with a Gram iodine solution for 1 minute and rinsed off using 95\% alcohol, which acted as a decolourising agent. Lastly, a safranin solution was used as a counterstain.

The slides were observed using a light microscope under 1000x magnification power. Bluish-purple colour represents the Grampositive LAB isolates. In endospore staining, slides with a heat-fixed smear were placed over a steaming water bath. Malachite green was applied for 5 minutes and rinsed off with water. A counterstain (safranin) was then added for 1 minute and rinsed with water again. Next, the slide was then observed using a light microscope under 1000x magnification power. This staining was used for further confirmation for the absence of endospore in all Lactobacillus strains. The reddish colour represents the nonspore forming $\mathrm{LAB}$ isolates.

The SEM method was carried out at the Institute of Oceanography and Environment (INOS), UMT, by modifying the procedures that have been used in previous studies due as specific chemicals were insufficient (Pyar \& Kok-Khiang, 2014). The bacterial cell pellets were collected after centrifugation for 5 minutes at $3000 \mathrm{rpm}$. The cell pellets were fixed with $2.5 \%$ glutaraldehyde in $0.1 \mathrm{M}$ sodium cacodylate buffer for 2 to 4 hours and were rinsed 3 times with a $0.1 \mathrm{M}$ sodium cacodylate buffer at $\mathrm{pH} 7.2$ 
in 15-minute intervals. Bacterial cell pellets were dehydrated by ethanol in a series of ascending gradation $(30 \%, 50 \%, 75 \%, 95 \%$ and $100 \%)$ in 10-minute intervals. The dried cell pellets were mounted on specimen stubs and coated with gold. Samples were observed using a scanning electron microscope at 10 to $25 \mathrm{kV}$.

\section{Biochemical Characterisation of $L A B$}

The biochemical characteristic of the pure cultures of LAB isolates were carried out through catalase, oxidase, and motility tests. A well-isolated and single colony of each LAB isolates was picked using a wooden applicator stick and placed on a microscope slide. A drop of $3 \%$ hydrogen peroxide $\left(\mathrm{H}_{2} \mathrm{O}_{2}\right)$ was applied on the isolated colony (Goyal, 2012; Hasali et al., 2015). The production of gas bubbles was recorded as catalase positive or vice versa. An oxidase test was performed using the filter paper method. Tetramethyl-p-phenylenediamine was used as an oxidase reagent. A few drops of the oxidase reagent were applied on filter paper and the well-isolated LAB colony was rubbed on the treated filter paper. The changing of the oxidised oxidase reagent from colourless to dark blue colour within 15 seconds indicates that it is oxidase positive. A motility test was performed to identify the ability of bacteria to move due to the presence of flagella. A SIM (Sulphide Indole Motility) medium was used perform motility test. Cells are stab-inoculated at the centre of the medium to a depth of half an inch.

\section{Physiological Characterisation of LAB}

The physiological characteristic of the LAB isolates from kefir milks were assessed by the growth of LAB isolates at different conditions, which are temperature, $\mathrm{pH}$, salinity, and bile salt concentrations, together with a carbohydrate fermentation test. MRS broth tubes were inoculated with active $\mathrm{LAB}$ isolates and incubated for 24 hours at temperatures $10^{\circ} \mathrm{C}$, $37^{\circ} \mathrm{C}$, and $45^{\circ} \mathrm{C}$. Meanwhile, a sterilised MRS broth with different $\mathrm{pH}$ (4.4 and 9.6) was prepared by adjusting the $\mathrm{pH}$ of the MRS broth with $0.1 \mathrm{~N} \mathrm{NaOH}$ and $0.1 \mathrm{~N} \mathrm{HCl}$ solutions. Some MRS broth tubes were prepared by incorporating $1 \%, 2 \%, 3 \%, 4 \%, 5 \%$ and $6 \%(\mathrm{w} / \mathrm{v})$ sodium chloride $(\mathrm{NaCl})$. Other tubes of MRS broth were prepared by adding $0.3 \%, 0.5 \%$ and $1.0 \%$ $(\mathrm{w} / \mathrm{v})$ bile salt (Oxoid, United Kingdom) into each tube, respectively. The sterilised MRS broth were inoculated with active $\mathrm{LAB}$ isolates and incubated for 24 hours at $37^{\circ} \mathrm{C}$. The growth of the LAB isolates in each condition was determined by turbidity and measured using a spectrophotometer at $600 \mathrm{~nm}$ by obtaining the optical density (Rhaiem et al., 2016). A phenol red broth was used as the medium in this test. Then, $1 \%$ of different sugar substrates, glucose, lactose, mannitol and sucrose were added into each phenol red broth tubes. Durham tubes were added into each phenol red tubes for the purpose of gas bubble detection. Sterilised phenol red broth tubes were inoculated with active $\mathrm{LAB}$ isolates and incubated for 24 hours at $37{ }^{\circ} \mathrm{C}$. The change of the phenol red broth from red to yellow indicates a positive reaction (Rhaiem et al., 2016).

\section{Phenotypic Identification of Lab Isolates using API 50 CHL Kit}

Pure colonies of overnight cultures of the LAB isolates, which were freshly grown on MRS plates at $37^{\circ} \mathrm{C}$ for 24 hours, were suspended in API $50 \mathrm{CH}$ mediums (Biomerieux, France). The suspension of each isolates was transferred into each of the 50 wells of the API $50 \mathrm{CH}$ strips, which contained different carbohydrates. After suspended, all wells were covered with sterilised mineral oil to make it anaerobic and incubated at $37^{\circ} \mathrm{C}$ for 24 and 48 hours as some LAB strains require longer time to complete carbohydrate fermentation (API 50 CHL Manual Kit, Biomerieux, France). Fermentation is revealed by a colour change in the tube, caused by the anaerobic production of acid and detected by the $\mathrm{pH}$ indicator present in the chosen medium. The results were analysed with API Web (Hasali et al., 2015). 


\section{Sensory Evaluation of Kefir Milk Samples}

The sensory evaluation was carried out to determine the preference of kefir milk with different substrates. Sensory attributes that were evaluated were appearance, colour, odour, taste, sourness and overall acceptance. The sample preparation for the kefir milks was performed by transferring $25 \mathrm{ml}$ of kefir milk into small plastic cup containers with a lid. The containers were coded with three random numbers and arranged according to permutations. All samples were evaluated by 30 volunteer panellists after the 24 hour production of kefir milks. The scoring used a 9-point hedonic scale, ranging from 1 (dislike extremely) to 9 (like extremely). The data from the sensory evaluation was subjected to a OneWay ANOVA using IBM SPSS (Version 20).

\section{Chemical Properties of Kefir Milk Samples}

The chemical properties of kefir milk samples were determined in terms of the $\mathrm{pH}$ levels and percentage of titratable acidity (\%TA) for lactic acid. The $\mathrm{pH}$ value of the kefir milks was measured analytically using a digital $\mathrm{pH}$ meter (PH700 Benchtop pH Meter, Oakton). The probe was first calibrated with buffers and the $\mathrm{pH}$ values of the kefir milks appeared on the screen as the probe was immersed into the kefir milks. The readings were then recorded as described by the manufacturer. The lactic acid in the kefir milks were measured by titrating the milk with a $0.1 \mathrm{~N} \mathrm{NaOH}$ solution (AOAC, 2000). The endpoint of the titration was detected as the colour of kefir milk turns the solution pink.

\section{Statistical Analysis}

Each data of the physicochemical properties, sensory acceptance and LAB count were subjected to a One-way Analysis of Variance (ANOVA) using IBM SPP Version 20.

\section{Results and Discussion}

\section{Isolation and Enumeration of $L A B$}

Results found that LAB were successfully isolated from kefir milks made from different milk substrates using standard microbiological procedures. The LAB counts from each sample kefir milks were enumerated and calculated as shown in Table 1. However, there were no significant differences in the LAB counts (CFU/ $\mathrm{ml})$ of each sample of the kefir milks $(p<0.05)$. Comparing each of the kefir milk sample, the coconut milk kefir had the highest count with $\log _{10} 9.11 \mathrm{CFU} / \mathrm{ml}$ on MRS Agar, $\log _{10} 9.12$ on MRS Agar added with $0.8 \% \mathrm{CaCO}_{3}$, and $\log _{10}$ 9.07 CFU/ml on M17 Agar, followed with cow milk kefir and soy milk kefir, respectively.

Table 1: LAB counts ( $\log 10 \mathrm{CFU} / \mathrm{ml})$ from sample kefir milks

\begin{tabular}{cccc}
\hline & \multicolumn{4}{c}{ Mean \pm SD $\left(\log _{10} \mathbf{C F U} / \mathbf{m l}\right)$} & \\
\hline Sample of Kefir & MRS Agar & MRS Agar + & M17 Agar \\
Milks & & $0.8 \% \mathrm{CaCO}_{3}$ & \\
Coconut Milk Kefir & $9.11 \pm 0.27^{\text {a }}$ & $9.12 \pm 0.17^{\text {a }}$ & $9.07 \pm 0.20^{\text {a }}$ \\
Cow Milk Kefir & $9.08 \pm 0.27^{\text {a }}$ & $9.02 \pm 0.27^{\text {a }}$ & $8.56 \pm 0.78^{\text {a }}$ \\
Soy Milk Kefir & $9.03 \pm 0.36^{\text {a }}$ & $9.01 \pm 0.34^{\text {a }}$ & $8.99 \pm 0.58^{\text {a }}$ \\
\hline
\end{tabular}

*Means with similar superscript indicates non-statistically significant different $(\mathrm{p}>0.05), \mathrm{n}=3$

According to Gülel (2014), probiotic products should have a minimum concentration of $10^{6} \mathrm{CFU} / \mathrm{ml}$ or CFU/g to provide a therapeutic effect. The LAB count from the three sample kefir milks showed high concentrations of CFU/ $\mathrm{ml}$, varying from $10^{8}$ to $10^{9} \mathrm{CFU} / \mathrm{ml}$, suggesting that all milks used exceed the minimum concentration of probiotic products. Moreover, the total presumptive LAB count found in soy milk was almost similar to the LAB count in soy milk kefir reported by Dadkhah et al. (2011). Previous research has shown that kefir made from cow milk using a commercial starter culture Lactococcus sp. predominated during 
the first $48 \mathrm{~h}$ of fermentation, at approximately $8.0 \log _{10} \mathrm{CFU} / \mathrm{g}$; Lactobacillus sp. became the predominant species after $48 \mathrm{~h}$, at approximately $8.5 \log _{10}$ CFU/g (García Fontán et al., 2006). Dadkhah et al. (2011) successfully reported that soy milk kefir produced using 3\% kefir grains had the highest Lactobacilli sp. levels (9.64 $\left.\pm 0.03 \log _{10} \mathrm{CFU} / \mathrm{ml}\right)$ and Lactococci sp. $\left(9.48 \pm 0.08 \quad \log _{10} \mathrm{CFU} / \mathrm{ml}\right)$. The finding is in agreement with other studies, in which Lactobacillus was reported to be present in cow milk and soy kefir milk. However, there have been no published data on the detection of Lactobacilli or Lactococci in coconut milk kefir. Therefore, this study is the first to report on the presence of Lactobacilli in coconut milk kefir.

\section{Morphological Characterisation of LAB}

From Table 2, all LAB isolates successfully grew on three different types of kefir milk samples. Cell morphology is important to determine the morphological characteristics of the LAB and their species genera. Through SEM, the results show that the kefir milks were dominated by rodshaped LAB cultures of LAB 001 as L. buchneri, LAB 002 as L. brevis, LAB 004 as L. acidophilus and LAB 005 as L. plantarum, whereas the cocci-shaped LAB 003 as Leu. mesenteroides. According to Elzeini et al. (2017), the shape of a bacterial cell influences many aspects of its life, including nutrient access, motility, chemotaxis, and resistance to predation. Five presumptive LAB isolates were morphologically investigated using SEM. The cells of each presumptive LAB isolates are photographed and representative images are shown in Figure 1.
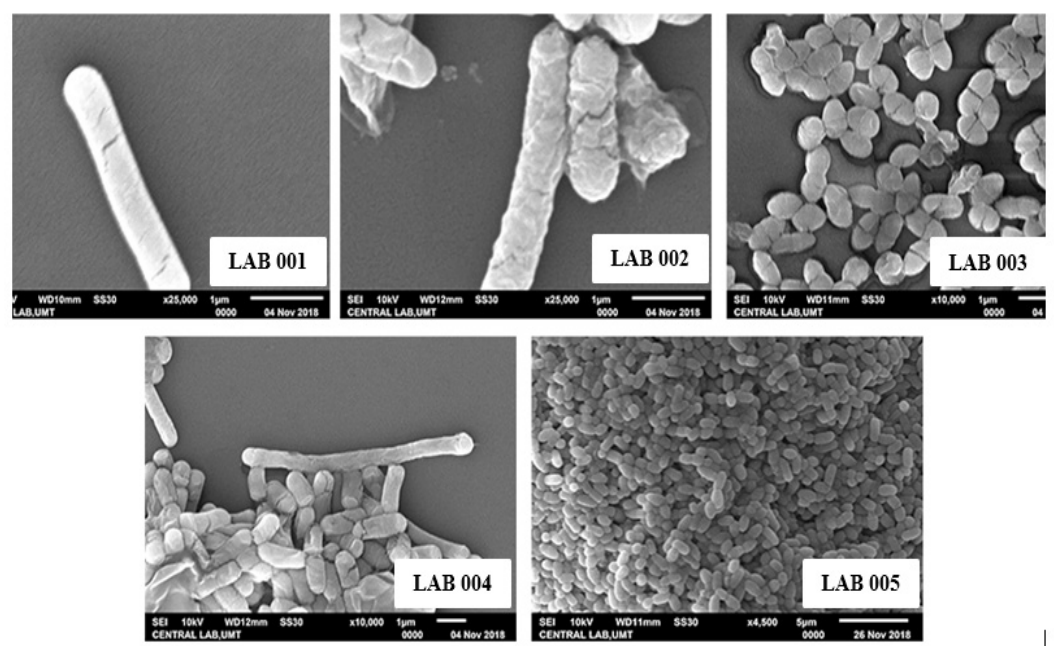

Figure 1: SEM observation on LAB isolates (LAB 001, LAB 002, LAB 004 and LAB 005 were rod-shaped, and LAB 003 was cocci-shaped)

Table 2: Identification and characteristic of LAB from sample kefir milks

\begin{tabular}{ccccccccc}
\hline \multirow{2}{*}{$\begin{array}{c}\text { Cultures } \\
\text { of LAB }\end{array}$} & \multicolumn{2}{c}{$\begin{array}{c}\text { Identification using } \\
\text { API 50 CHL }\end{array}$} & \multicolumn{2}{c}{ Morphological characterisation } & \multicolumn{3}{c}{ Biochemical characterisation } \\
\cline { 2 - 8 } & $\begin{array}{c}\text { Similarity } \\
\mathbf{( \% )}\end{array}$ & $\begin{array}{c}\text { Identification } \\
\text { ID }\end{array}$ & Morphology & $\begin{array}{c}\text { Gram } \\
\text { Staining }\end{array}$ & $\begin{array}{c}\text { Endospore } \\
\text { Staining }\end{array}$ & $\begin{array}{c}\text { Oxidase } \\
\text { Test }\end{array}$ & $\begin{array}{c}\text { Catalase } \\
\text { Test }\end{array}$ & $\begin{array}{c}\text { Motility } \\
\text { Test }\end{array}$ \\
\hline $\begin{array}{c}\text { LAB } \\
\mathbf{0 0 1}\end{array}$ & $82.50 \%$ & $\begin{array}{c}\text { Lactobacillus } \\
\text { buchneri }\end{array}$ & Rod Shaped & + & - & - & - & - \\
LAB & $93.20 \%$ & $\begin{array}{c}\text { Lactobacillus } \\
\text { brevis } 1\end{array}$ & Rod Shaped & + & - & - & - & - \\
$\mathbf{0 0 2}$ & & & & & - & - & - \\
\hline
\end{tabular}




\begin{tabular}{|c|c|c|c|c|c|c|c|c|}
\hline $\begin{array}{c}\text { LAB } \\
003\end{array}$ & $99.90 \%$ & $\begin{array}{l}\text { Leuconostoc } \\
\text { mesenteroides } \\
\text { ssp. } \\
\text { mesenteroides }\end{array}$ & Cocci Shaped & + & - & - & - & - \\
\hline $\begin{array}{c}\text { LAB } \\
004\end{array}$ & $67.50 \%$ & $\begin{array}{l}\text { Lactobacillus } \\
\text { acidophilus } 3\end{array}$ & Rod Shaped & + & - & - & - & - \\
\hline $\begin{array}{c}\text { LAB } \\
005\end{array}$ & $99.80 \%$ & $\begin{array}{c}\text { Lactobacillus } \\
\text { plantarum } 1\end{array}$ & $\begin{array}{l}\text { Short Rod } \\
\text { Shaped }\end{array}$ & + & - & - & - & - \\
\hline
\end{tabular}

${ }^{*}(+)$ indicates the positive result, (-) indicates the negative result

All the LAB isolates were Gram-positive and non-spore forming bacteria. Gram-positive LAB stain dark blue due to the presence of a thick layer of peptidoglycan within their cell walls. According to Chapot-Chartier and Kulakauskas (2014), LAB consist of a thick peptidoglycan sacculus that surrounds the cytoplasmic membrane and are decorated with teichoic acids, polysaccharides, and proteins. The thick peptidoglycan layer protects from the dehydrating effect of decolourising agent (95\% alcohol) that extracts the crystal violet iodine complex (CV-I) from the cell walls. Generally, LAB do not contain bacterial endospores, which are metabolically inactive and highly resistant to unfavourable environmental conditions. According to Oktari et al. (2017), malachite green and safranin were able to work well in bacteria due to their alkalinity (chromophore component positively charged), while the bacterial cytoplasm is basophilic, so there was an attraction between the components chromophore in the stains with bacterial cells, resulting in the bacteria being able to absorb the stains well.

\section{Phenotypic Characterisation of LAB using Biochemical Tests and API 50 CHL Kit}

From Table 2, all LAB isolates from the sample kefir milks of coconut milk kefir, cow milk kefir and soy milk kefir were confirmed as oxidase negative, catalase negative and non-motility by a series of biochemical characterisation tests. The negative results of the LAB isolates from kefir milks directly indicated that the absence of enzyme cytochrome c oxidase in LAB isolates, which react with oxygen to form a coloured end product. This is supported by Ouoba et al. (2009), who stated that the isolated LAB from African traditional alkaline-fermented foods were oxidase negative. The catalase enzyme recomposited hydrogen peroxide to water and oxygen. In order to survive, some bacteria rely on defence mechanisms that protect them from bactericidal effects of hydrogen peroxide through the production of enzyme catalase (Pine et al., 1984). Sefidgar et al. (2014) reported that LAB isolated from Iranian kefir drink was also catalase negative. Based on the results of motility test, all LAB isolates were categorised as non-motile bacteria.

Using the API 50 CHL kit, this study confirmed that among the five LAB isolates randomly taken from all three samples of kefir milks, four of them were belong to Lactobacillus $\mathrm{sp}$. and one isolates belong to Leuconostoc sp. as shown in Table 2. LAB 002, LAB 003 and LAB 005 showed high similarity to Lactobacillus brevis 1 (93.2\%), Leuconostoc mesenteroides ssp. mesenteroides (99.9\%) and Lactobacillus plantarum 1 (99.8\%). The presence of viable and potential probiotic Lactobacilli in kefir milks showed that LAB play an important role in probiotic drinks. Maekawa et al. (2014) proved that probiotic L. brevis can inhibit periodontitis through modulatory effects on the host response and the periodontal microbiota.

\section{Physiological Characterisation of LAB}

The physiological characteristics of the five presumptive $\mathrm{LAB}$ isolates were determined by temperature, $\mathrm{pH}$, salt, bile and salt tolerance, 
as well as carbohydrate fermentation tests. isolates produce lactic acid, which then react From Table 3, it is shown that the selected $\mathrm{LAB}$ with $\mathrm{CaCO}_{3}$ to produce calcium lactate as the isolates were acid-producing bacteria, due to end product and form a clear zone surrounding their reaction with $\mathrm{CaCO}_{3}$. Acid-producing $\mathrm{LAB}$ the colonies of the LAB isolates.

Table 3: Physiological characterisation of LAB

\begin{tabular}{cccccc}
\hline \multicolumn{5}{c}{ Physiological characterisation } \\
\hline $\begin{array}{c}\text { Physiological } \\
\text { Tests }\end{array}$ & $\begin{array}{c}\text { Lactobacillus } \\
\text { buchneri }\end{array}$ & $\begin{array}{c}\text { Lactobacillus } \\
\text { brevis 1 }\end{array}$ & $\begin{array}{c}\text { Leuconostoc } \\
\text { mesenteroides }\end{array}$ & $\begin{array}{c}\text { Lactobacillus } \\
\text { acidophilus } 3\end{array}$ & $\begin{array}{c}\text { Lactobacillus } \\
\text { plantarum 1 }\end{array}$ \\
\hline
\end{tabular}

Fermentation Heterofermentative Heterofermentative Heterofermentative Homofermentative Heterofermentative Pattern

Clear Zone

Acid

Tolerance

pH 4.4

pH 9.6

Temperature

Tolerance

$10^{\circ} \mathrm{C}$

$37^{\circ} \mathrm{C}$

$45^{\circ} \mathrm{C}$

Salt Tolerance

$1 \% \mathrm{NaCl}$

$2 \% \mathrm{NaCl}$

$3 \% \mathrm{NaCl}$

$4 \% \mathrm{NaCl}$

$5 \% \mathrm{NaCl}$

$6 \% \mathrm{NaCl}$

Bile Salt

Tolerance

0.3\% Bile

Salt

$0.5 \%$ Bile

Salt

1\% Bile Salt

$++$

$+$

$++$

$+$

Sugar

Fermentation

Glucose

Lactose

Mannitol

$+$

$++$

$-$

$++$

$++$

$++$

-

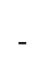

$-$

$++$

$+$

$+$
$++$

$++$

$++$

$++$

$++$

$-$

$-$

$++$

$++$

$++$
$+$

$++$

$-$

$++$

$+$

$+$

$+$

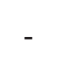

$-$

$++$

$+$

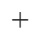

$++$

Sucrose

$\begin{array}{lll}- & ++ & + \\ - & ++ & - \\ - & ++ & + \\ ++ & ++ & +\end{array}$

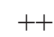

$++$

$++$

$++$

$++$ 
From Figure 2, the results revealed that all the LAB isolates were highly resistant to acidity conditions. At $\mathrm{pH} 4.4$, all the $\mathrm{LAB}$ isolates grew significantly with high optical density value at $600 \mathrm{~nm}$, ranging from 0.713 to $1.384 \mathrm{OD}_{600}$, indicating that all the LAB isolates were acid tolerant. It is interesting to note that among five LAB isolates, L. buchneri, L. brevis 1, and Leu. mesenteroides sp. mesenteroides were able to survive high $\mathrm{pH}$ levels, or alkalinity conditions, with an $\mathrm{OD}_{600}$ value of $0.452,0.242$ and 0.740 , respectively. The regulation of the cytoplasmic $\mathrm{pH}$ helped the LAB adapt to the acidity or alkalinity conditions. Nyanga-Koumou et al. (2012) accepted that bacterial cytoplasmic $\mathrm{pH}$ is regulated by various cations transport systems to maintain normal LAB cellular activities and functions. This allows acid-resistant LAB to not only withstand the high $\mathrm{pH}$ of gastric juices, but also enables them to survive for longer period in acidic foods, such as kefir and sauerkraut.

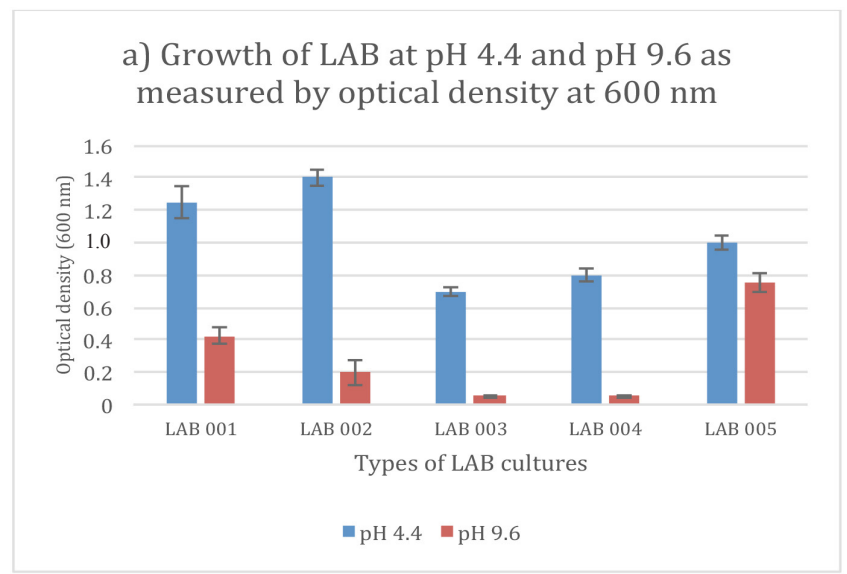

*LAB 001: L. buchneri; LAB 002: L. brevis 1; LAB 003: Leu. mesenteroides ssp. mesenteroides; LAB 004: L. acidophilus 3 and LAB 005: L. plantarum 1

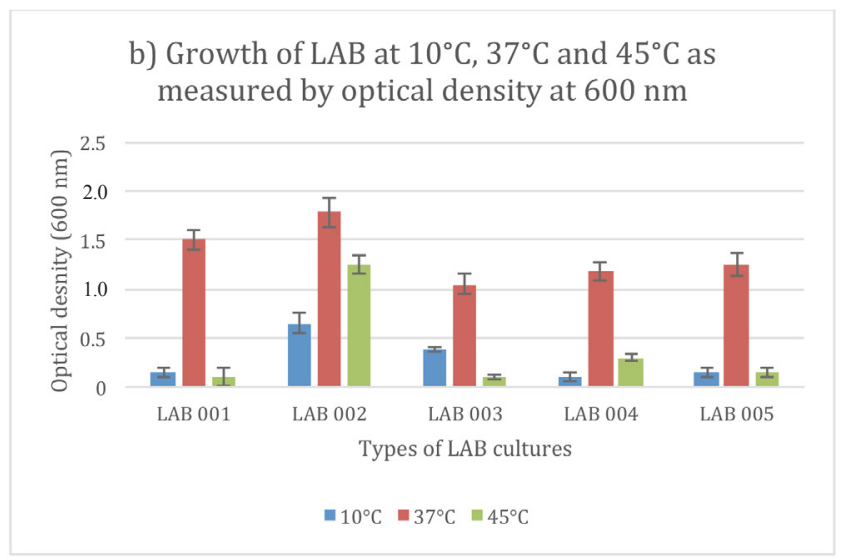

*LAB 001: L. buchneri; LAB 002: L. brevis 1; LAB 003: Leu. mesenteroides ssp. mesenteroides; LAB 004: L. acidophilus 3 and LAB 005: L. plantarum 1 


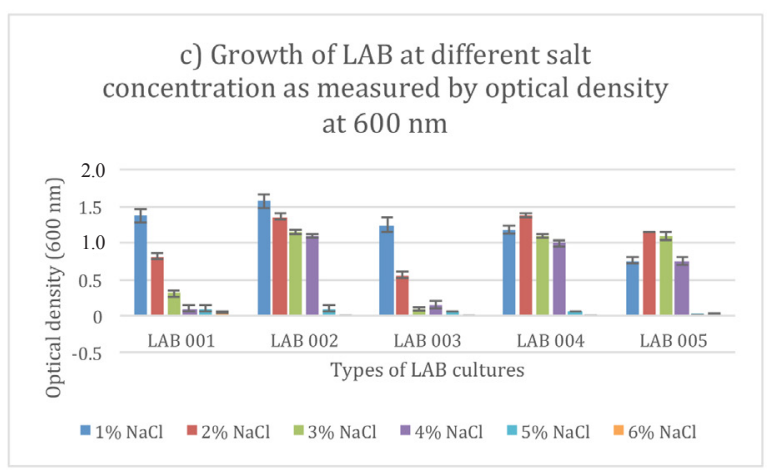

*LAB 001: L. buchneri; LAB 002: L. brevis 1; LAB 003: Leu. mesenteroides ssp. mesenteroides; LAB 004: L. acidophilus 3 and LAB 005: L. plantarum 1

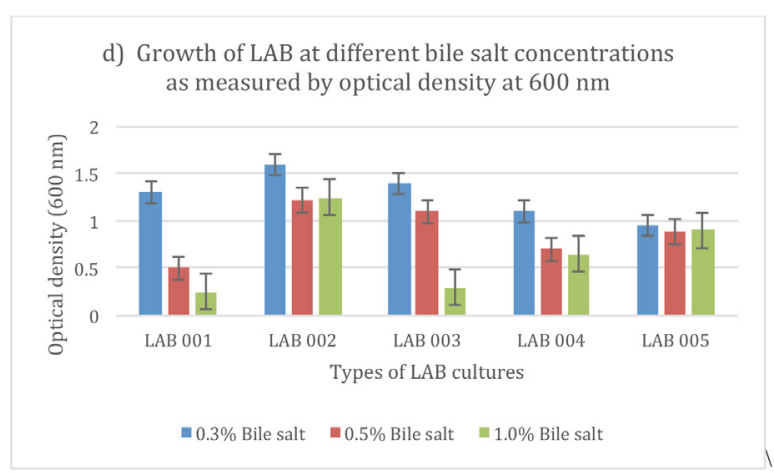

*LAB 001: L. buchneri; LAB 002: L. brevis 1; LAB 003: Leu. mesenteroides ssp. mesenteroides; LAB 004: L. acidophilus 3 and LAB 005: L. plantarum 1.

Figure 2: The growth of LAB isolates at different conditions measured by optical density at $600 \mathrm{~nm}$ (adifferent $\mathrm{pH}, \mathrm{b}$ - different temperatures, c- different salt concentrations and d- different bile salt concentrations)

\section{Sensory Evaluation}

Table 4 represents the sensory analysis for the kefir milk samples based on six sensory attributes, which are appearance, colour, odour, taste, sourness, and overall acceptance. Cow milk kefir has the highest mean score of 6.80 for appearance, 7.23 for colour, 6.80 for odour, 7.27 for taste, 6.07 for sourness and 6.70 for overall acceptance, compared with coconut and soy milk kefirs. This indicates that most of the panellists preferred cow milk kefir over coconut milk kefir and soy milk kefir in the sensory evaluation on each attribute. Overall, the panellists liked the colour and taste of cow milk kefir moderately with high overall acceptance than coconut and soy milk kefirs, but liked the appearance, odour, and sourness of cow milk kefir slightly. Based on the results, cow milk kefir differed significantly $(p<0.05)$ than coconut and soy milk kefirs in the evaluation of appearance, colour, odour, texture and overall acceptance, but showed no significant difference $(p>0.05)$ with coconut and soy milk kefirs in the evaluation of sourness. Besides, there was no significant difference $(p>0.05)$ between coconut and soy milk kefirs in the evaluation of all attributes. According to Irigoyen, 2004, kefir products from dairy animals, such as cow, goat, sheep, camel, buffalo, have a $\mathrm{pH}$ value of around 4.0, alcohol content ranging from $0.5 \%$ to $2 \%$, and fat content ranging from 3.3 to $7 \%$. The cow milk kefir taste is acidic, prickly, and slightly yeasty. The sharp 
acid and yeasty flavour, together with the prickly sensation contributed by the carbon dioxide produced by the yeast flora can be considered as the typical kefir flavour. Furthermore, during the fermentation, vitamin B1, B12, calcium, amino acids, folic acid and vitamin $\mathrm{K}$ increase in the cow milk kefir (Otles \& Cadingi, 2003).

Table 4: Sensory Analysis of kefir milks

\begin{tabular}{ccccccc}
\hline \multicolumn{5}{c}{ Sensory Analysis (Mean Score \pm SD) } \\
\hline $\begin{array}{c}\text { Sample of } \\
\text { Kefir Milk }\end{array}$ & Appearance & Colour & Odour & Taste & Sourness & $\begin{array}{c}\text { Overall } \\
\text { Acceptance }\end{array}$ \\
\hline $\begin{array}{c}\text { Coconut } \\
\text { Milk Kefir }\end{array}$ & $5.57 \pm 1.91^{\mathrm{b}}$ & $5.77 \pm 1.72^{\mathrm{b}}$ & $5.53 \pm 1.46^{\mathrm{b}}$ & $5.17 \pm 0.83^{\mathrm{b}}$ & $6.03 \pm 2.19^{\mathrm{a}}$ & $5.20 \pm 1.06^{\mathrm{b}}$ \\
\hline $\begin{array}{c}\text { Cow Milk } \\
\text { Kefir }\end{array}$ & $6.80 \pm 1.52^{\mathrm{a}}$ & $7.23 \pm 1.30^{\mathrm{a}}$ & $6.80 \pm 0.96^{\mathrm{a}}$ & $7.27 \pm 0.69^{\mathrm{a}}$ & $6.07 \pm 1.28^{\mathrm{a}}$ & $6.70 \pm 0.65^{\mathrm{a}}$ \\
\hline $\begin{array}{c}\text { Soy Milk } \\
\text { Kefir }\end{array}$ & $5.37 \pm 0.85^{\mathrm{b}}$ & $5.13 \pm 1.00^{\mathrm{b}}$ & $5.03 \pm 0.96^{\mathrm{b}}$ & $5.00 \pm 1.20^{\mathrm{b}}$ & $5.07 \pm 1.51^{\mathrm{a}}$ & $5.03 \pm 0.49^{\mathrm{b}}$ \\
\hline
\end{tabular}

*Means with different superscript indicate statistically significant different $(p<0.05)$

Table 5: Physicochemical properties of kefir milks

\begin{tabular}{lcc}
\hline & \multicolumn{2}{c}{ Mean \pm SD } \\
\hline Sample of Kefir Milks & pH & TA (\% of Lactic Acid) \\
\hline Coconut Milk Kefir & $4.10 \pm 0.02^{\mathrm{c}}$ & $1.29 \pm 0.07^{\mathrm{a}}$ \\
Cow Milk Kefir & $4.21 \pm 0.03^{\mathrm{b}}$ & $0.99 \pm 0.02^{\mathrm{b}}$ \\
Soy Milk Kefir & $4.34 \pm 0.11^{\mathrm{a}}$ & $0.71 \pm 0.01^{\mathrm{c}}$ \\
\hline
\end{tabular}

*Means with different superscript indicate statistically significant different $(\mathrm{p}<0.05)$

\section{Conclusion}

From this study, five different strains of LAB have been isolated from different milk substrates (cow milk, coconut milk and soy milk) of kefir milks, which are L. buchneri, L. brevis, Leu. mesenteroides, L. acidophilus and $L$. plantarum. This study showed that the different milk substrates have a significant effect on the physiochemical and sensory properties of the three different kefir milks. Further investigation should be focused on the probiotic characteristics of kefir milks and their effects on gut microbiota. Our findings are relevant and useful to manufacturers in the probiotic industry in the production of alternative probiotic products for dairy and non-dairy consumers (those who are lactose intolerant and vegetarian).

\section{Acknowledgements}

The authors would gratefully like to acknowledge the laboratory and monetary support given by the Faculty of Fisheries and Food Science, Universiti Malaysia Terengganu, Malaysia.

\section{References}

AOAC (2000). Official method of analysis. 16th edition. Washington D.C: Association of Official Analytical Chemists.

Bourrie, B. C. T., Willing, B. P., \& Cotter, P. D. (2016). The microbiota and health promoting characteristics of the fermented beverage kefir. Frontiers in Microbiology, 7, 647. https://doi.org/10.3389/fmicb.2016.00647 
Chapot-Chartier, M. P. \& Kulakauskas, S. (2014). Cell wall structure and function in lactic acid bacteria. Microbial Cell Factories, 13(Suppl 1), S9. https://doi. org/10.1186/1475-2859-13-S1-S9.

Dadkhah, S., Pourahmad, R., Assadi, M. M., \& Moghimi, A. (2011). Kefir production from soymilk. Annals of Biological Research, 2(6), 293-299.

Elzeini, H. M, Ali, A. A., Nasr, N. F., Awad, A. A., \& Hassan, A. A. (2017). Morphological and rheological identification of cocci lactic acid bacteria. Journal of Microbial and Biochemical Technology, 9(1), 519-526.

Font de Valdez, G., Rollán, G., Gerez, C. L., \& Torino, M. I. (2011). Microbial applications in the biopreservation of cereal products. Protective Cultures, Antimicrobial Metabolites and Bacteriophages for Food and Beverage Biopreservation, Woodhead Publishing Series in Food Science, Technology and Nutrition. pp. 348-363.

Garcia Fontan, M. C., Martinez, S., Franco, I., \& Carballo, J. (2006). Microbiological and chemical changes during the manufacture of Kefir made from cows' milk, using a commercial starter culture. International Dairy Journal, 16, 762-767.

Gaware, V., Kotade, K., \& Dolas, R. (2011). The magic of Kefir: A review history of Kefir. Pharmacology online, 1, 376-386.

Goyal, R. (2012). Characterisation of the Lactobacillus isolated from different curd samples. African Journal of Biotechnology, 11(79), 14448-14452.

Granato, D., Branco, G. F., Nazzaro, F., Cruz, A. G., \& Faria, J. A. (2010). Functional foods and non-dairy probiotic food development: Trends, concepts, and products. Comprehensive Review in Food Science and Food Safety, 9, 292-302.

Gulel, S. (2014). Molecular identification and probiotic properties of Lactobacillus acidophilus group isolates from Turkish Kefir. M. Sc. Thesis. Middle East Technical University, Turkey.
Hasali, N. H. M., Zamri, A. I., Lani, M. N., Mubarak, A., \& Suhaili, Z. (2015). Identification of lactic acid bacteria from Meliponine honey and their antimicrobial activity against pathogenic bacteria. American-Eurasian Journal of Sustainable Agriculture, 9(6), 1-7.

Hass, R., Schnepps, A., Pichler, A., \& Meixner, O. (2019) Cow milk versus plant-based milk substitutes: A comparison of product image and motivational structure of consumption. Sustainability, 11, 5046, 1-25. doi:10.3390/ su11185046

Irigoyen, A., Arana, I., Castiella, M., Torre, P., \& Ibanez, F. C. (2005). Microbiological, physicochemical, and sensory characteristics of kefir during storage. Food Chemistry, 90(4), 613-620.

Lani, M., Nor, N., Ramli, N., Radhuan, Z., Rizan, M., Lokman, N., \& Hassan, Z. (2015). Effects of incorporation of lactic acid bacteria on microbiological quality and shelf life of raw 'Satar'. In Beneficial Microorganisms in Food and Nutraceuticals (pp. 81-109). Springer, Cham.

Lee, A. L. C. N., Lani, M. N., Alias, R. \& Hassan, Z. (2019). Lactic acid bacteria isolated from locally produced vinegars and their antibacterial activity against foodborne bacteria. UMT Universiti Malaysia Terengganu Journal of Undergraduate Research, 2, 1-7.

Maekawa, T. \& Hajishengallis, G. (2014). Topical treatment with probiotic Lactobacillus brevis CD2 inhibits experimental periodontal inflammation and bone loss. Journal of Periodontal Research, 49(6), 785-791.

Magalhães, K. T., Pereira, G. V. de M., Campos, C. R., Dragone, G., \& Schwan, R. F. (2011). Brazilian kefir: structure, microbial communities and chemical composition. Brazilian Journal of Microbiology, 42(2), 693-702.

McKevith, B. \& Shortt, C. (2003). Fermented milks: Other relevant products. Encyclopedia 
of Food Sciences and Nutrition, 2383$2389 . \quad$ https://doi.org/10.1016/B0-12227055-X/00458-2.

Mattila-Sandholm, T., Myllärinen, P., Crittenden, R., Mogensen, G., Fondén, R. \& Saarela, M. (2002). Technological challenges for future probiotic foods. International Dairy Journal, 12(2-3), 173-182.

Nyanga-Koumou, A. P., Ouoba, L. I. I., Kobawila, S. C. \& Louembe, D. (2012). Response mechanisms of lactic acid bacteria to alkaline environments: A review. Critical Reviews in Microbiology, 38(3), 185-190. https://doi.org/10.3109/104084 1X.2011.640978.

Oktari, A., Supriatin, Y., Kamal, M. \& Syafrullah, H. (2017). The bacterial endospore stain on Schaeffer Fulton using variation of methylene blue solution. Journal of Physics: Conference Series, 812 (2017), 012066. https://doi.org/10.1088/17426596/812/1/012066.

Otles, S., \& Cagindi, O. (2003). Kefir: A probiotic dairy-composition, nutritional and therapeutic aspects. Pakistan Journal of Nutrition, 2(2), 54-59.

Oner, Z., Karahan, A. G., \& Cakmakci, M. L. (2010). Effects of different milk types and starter cultures on kefir. Gida, 35(3), 177182.

Ouoba, L. I. I., Nyanga-Koumou, C. A. G., Parkouda, C., Sawadogo, H., Kobawila, S. C., Keleke, S., \& Sutherland, J. P. (2009). Genotypic diversity of lactic acid bacteria isolated from African traditional alkalinefermented foods. Journal of Applied Microbiology, 108(6), 2019-2029.

Pine, L., Hoffman, P. S., Malcolm, G. B., Benson, R. F., \& Keen, M. G. (1984). Determination of catalase, peroxidase, and superoxide dismutase within the genus Legionella.
Journal of Clinical Microbiology, 20(3), 421-429.

Pyar, H. \& Kok-Khiang, P. (2014) Characterization and identification of Lactobacillus acidophilus using biolog rapid identification system. International Journal of Pharmacy and Pharmaceutical Sciences, 6(1), 189-193

Raja, B. R., \& Arunachalam, K. D. (2011). Market potential for probiotic nutritional supplements in India. African Journal of Business Management, 5(14), 5418-5423.

Rattanachaikunsopon, P. \& Phumkhachorn, P. (2010). Lactic acid bacteria: their antimicrobial compounds and their uses in food production. Scholars Research Library Annals of Biological Research, 1(4), 218-228.

Rhaiem, N., Chahboun, N., Inekach, S., \& Ouhssine, M. (2016) Identification and characterisation of lactic acid bacteria isolated from cow milk and olives brine. Journal of Materials and Environmental Science, 7(5), 1504-1509.

Ruiz-Rodríguez, L., Bleckwedel, J., Eugenia Ortiz, M., Pescuma, M. \& Mozzi, F. (2017). Lactic acid bacteria. in: industrial biotechnology: microorganisms. Volume 1. (pp. 395-451). Weinheim, Germany: Wiley-VCH Verlag GmbH \& Co. KGaA.

Sefidgar, S. A. A., Gharekhani, S., \& Ghasempour, M. (2014). Identification of yeasts and bacteria isolated from Iranian kefir drink. Jundishapur Journal of Microbiology, 7(2), e10707.

Wojtowski, J., Dankow, R., Skrzyper, R., \& Fahr, R. D. (2003). The fatty acid profile in kefirs from sheep, goat and cow milk. Milchwissenschaf, 58(11/12), 633-636. 
